\title{
Strategi Pemasaran Komunitas Pedagang Berbasis Online dan Personalisasi Pemasaran Terhadap Kinerja Pemasaran
}

\author{
Taat Kuspriyono \\ Universitas Bina Sarana Informatika \\ e-mail: taat.tat@bsi.ac.id
}

\begin{abstract}
Abstrak - Belanja online semakin diminati oleh berbagai kalangan karena berbagai kemudahan yang diberikan baik dalam bertransaksi maupun keamanan. Masing-masing pedagang e-commerce saling memberikan bonus ataupun diskon untuk menarik minat pelanggan. Untuk membangun kerjasama tim serta sharing berbagai pengalaman terkait dengan penjualan tidak jarang banyak pedagang online yang membentuk suatu komunitas. Bahkan keuntungan lain yang didapatkan oleh pedagang online adalah dapat melakukan strategi pemasaran secara personalisasi. Strategi personalisasi ini dinilai cukup efektif dalam mencari konsumen berdasarkan pesan yang dikirimkan oleh pedagang kepada konsumen. Namun pada dasarnya semua hal yang dilakukan tersebut dilakukan untuk meningkatkan hasil penjualan. Jumlah hasil penjualan dapat dilihat dari kinerja pemasaran yang dilakukan. Melalui kinerja tersebut dapat diketahui sampai sejauh mana kinerja pedagang dalam memasarkan barang. Dalam hal ini pedangang merupakan seorang yang berperan akif dalam penjualan. Dengan sistem personalisasi pemasaran pedagang dapat memperkirakan barang yang dibutuhkan oleh konsumen. Metode yang dilakukan dalam penelitian ini menggunakan metode kuantitatif dengan pengumpulan data melalui penyebaran kuesioner. Data kuesioner yang telah diisi oleh konsumen diolah dengan menggunakan software SPSS. Hasil penelitian menunjukan bahwa strategi pemasaran komunitas pedangang online dan personaliaasi pemasaran secara simultan berpengaruh terhadap kinerja pemasaran.
\end{abstract}

Kata Kunci : Komunitas Online, Personalisasi Pemasaran, Kinerja Pemasaran

\begin{abstract}
Online shopping is increasingly in demand by various groups because of the various conveniences provided both in transactions and security. Each e-commerce merchant gives each other bonuses or discounts to attract customers. To form teamwork and share various experiences related to sales, it is not uncommon for many online merchants to form a community. In fact, another advantage gained by online merchants is being able to personalize marketing strategies. This personalized style is considered quite effective in finding consumers based on messages sent by merchants to consumers. But basically all of the things done are done to improve the results of selling. The amount of sales can be seen from the marketing performance carried out. Through this performance can be known to what extent the performance of traders in marketing goods. In this case the sword is a person who plays an active role in sales. With a marketing personalization system the merchant can estimate the goods needed by consumers. The method used in this study uses quantitative methods by collecting data through questionnaires. Questionnaire data that has been filled out by consumers will be processed using SPSS software. The results of the study showed that the online marketing strategy of the online community and marketing personnel simultaneously affected the marketing performance.
\end{abstract}

Keywords: Online Community, Marketing Personalization, Marketing Performance

\section{PENDAHULUAN}

Saat ini belanja online telah meraja di berbagai kalangan, baik remaja, dewasa maupun orang tua. Saling bermunculnnya situs belanja online secara tidak langsung telah membuktikan bahwa masyarakat sangat berantusias dengan jenis belanja yang berbasis digital ini. Belanja online terus diminati oleh berbagai kalangan, mulai dari kemudahan, kenyamanan serta berbagai bonus atau diskon yang dibelikan kepada para pedagang.
Banyaknya para pedagang online yang memberikan berbagai potongan harga menyebabkan semakin berlomba lombanya pedagang e-commerce yang mencari konsumen dengan cara dan strategi masing-masing. Kemudahan dan keamanan membuat situs belanja online saling menampilkan keuntungan dan kelebihan dari situs ini

Sangat mudah akses yang diberikan dalam berbelanja online memungkinkan siapapun dapat memesan barang keinginannya dimanapun mereka 
berada. Hadirnya komunitas belanja online membuat para pedagang online dalam memasarkan produk bertujuan sebagai bagian dari kerja sama antar pedagang dalam membangun jaringan atau link.

Dengan terbentuknya komunitas antar pedagang online tentunya dapat menjalin kerja sama kepada seluruh komunitas online untuk saling bertukar pikiran atau sharing mengenai berbagai hal, terkait dengan penjualan dan konsumen.

Namun yang tidak kalah terpenting dan harus diperhatikan dalam hal ini adalah pedagang $e$ commerce dapat membentuk pesan tertentu kepada konsumen yang dikira dapat menjadi pembeli produk tersebut atau istilah lainya dalam pemasaran disebut dengan personalisasi pemasaran.

Tentunya dengan dibentuknya komunitas pedangan online dan personalisasi pemasaran dapat meningkatkan kinerja pemasaran. Kinerja pemasaran dapat dilihat dengan jelas melalui peningkatan jumlah penjualan. Tidak dapat dipungkiri bahwa pada dasarnya tujuan dari seluruh komunitas pedagang online dalam menjalankan bisnis tersebut tidak lain untuk meningkatkan jumlah penjualan. Namun untuk memastikan dan membuktikan secara lebih lanjut maka perlu diadakan suatu penelitian terkait "Strategi pemasaran berbasis komunitas pedagang online dan personalisasi pemasaran terhadap kinerja pemasaran".

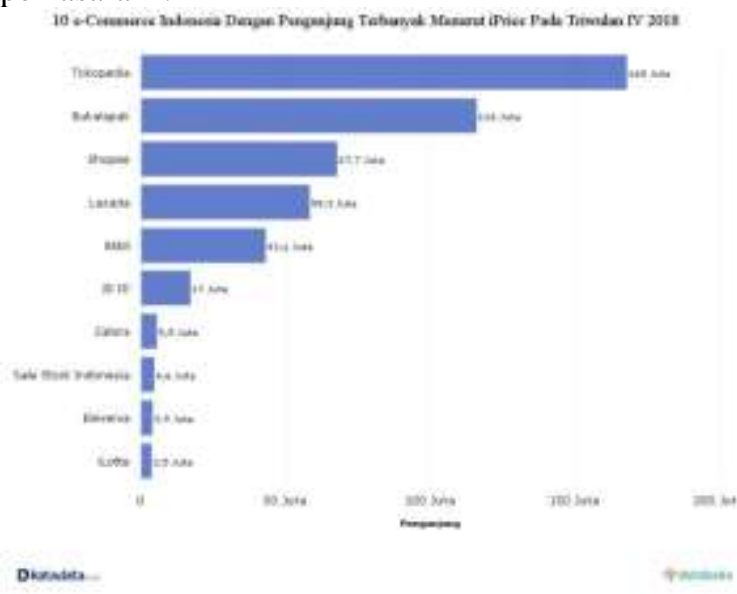

Gambar 1. Gambar e-Commerce Indonesia Paling Diminati pada Triwulan IV 2018

Sumber : (“databoks.katadata," n.d.)

\section{Strategi Pemasaran}

Strategi pemasaran akan berpengaruh pada penentuan produk (termasuk nama atau merek dan kemasan), penetapan harga, dan penempatan produk di media online (digital precense). (Rusmanto, 2017)

Strategi pemasaran itu antara lain menetapkan target pasar untuk produk yang akan dipasarkan sesuai segmen-segmen pasar yang ada.
Kemudian menentukan posisi produk di pasar terhadap produk lain atau pesaing. Ketiga proses penyusunan strategi pemasaran ini disingkat STP) (Segmenting, Targeting, Positioning).

\section{Komunitas}

Menurut Rothaermel dan Sugiyama dalam (Kristiadi, 2018), komunitas adalah wadah berbagi bersama (sharing) yang terbentuk secara rutin oleh para pihak yang memiliki minat yang sama. Sementara itu Albert Muniz dan Thomas O'Guinn dalam (Kristiadi, 2018), mendefinisikan komunitas sebagai bentuk asosiasi yang diperlukan dalam rangka konsumsi atas suatu barang atau layanna. Mereka menemukan bahwa pemasaran tidak lagi menjalankan strategi pemasaran dan segmentasi, melainkan beralih membagi pasar ke dalam komunitas-komunitas. Fenomena ini menyebabkan munculnya strategi pemasaran yang berbasis komunitas. Strategi ini kemudian berkembang dan komunitas yang menjadi perhatian pemasar adalah komunitas merek.

Komunitas bisa terjadi dari interaksi sejumlah pihak (pembeli, pemasok, dan pihak terkait lainnya), sehingga membentuk sebuah keterkaitan . Ada tiga syarat utama agar sebuah kelompok bisa disebut komunitas, yaitu sebagai berikut:

1. Adanya kesadaran bersama (consciousness of kind), yaitu: kesadaran akan kebaikan dan membangun hubungan batin yang sama antaranggota.

2. Adanya ritual bersama dan tradisi, sehingga membentuk kominitas memiliki sejarah, kultur, dan pemikiran yang sama.

3. Adanya tanggung jawab moral, baik kepada komunitas maupun anggota perorangan.

Secara bahasa online berarti on-line dalam baris secara istilah online diartikan teruta ketika jika digunakan dalam percangkapan umum "saya sedang online" dapat dimengerti seseorang sedang terhubung dengan jaringan (network) yang lebih besar seperti Internet atau sedang terhubung dengan orang lain melalui jaringan telepon. (Ramadhan, 2013)

\section{Personalisasi Pemasaran}

Teknologi e-commerce menungkinkan dilakukanya personalisasi (personalizztion): Pedang dapat mengarahkan pesan pemasarannya pada orang-orang tertentu dengan menyesuaikan dilakukannya penyeseuaiannya (customization)mengubah barang atau jasa yang dijual sesuai dengan presensi pengguna atau perilaku yang ia tunjukkan sebelumnya. Berdasarkan sifat interaktif dari teknologi e-commerce, lebih banyak informasi tentang konsumen yang dapat diperoleh di pasar pasa saat terjadi pembelian. Dengan meningkatnya kepadatan informasi, kococokan yang tentang pembelian di masa lalu dan perilaku konsumen 
dapat disimpan dan dimanfaatkan oleh para penjual online. (Laoudon, Kenneth C. dan Laudon, 2008)

Hasilnya adalah tingkat personalisasi dan penyesuaian yang tidak terbayangkan sebelumnya dengan teknologi perdagangan yang tradisional. Sebagai contoh, sesorang mungkin dapat menentukkan apa yang dilihat di televisi dengan memilih saluran yang dinginkan, tetapi tidak akan dapat mengubah isi dari saluran yang telah Anda pilih. Kebalikannya, jalan online memungkinkan memilih jenis cerita/berita yang ingin dilihat terlebih dahulu, dan memberikan kesempatan untuk selalu diberitahu ketika peristiwa-peristiwa tertentu terjadi.

\section{Kinerja Pemasaran \\ Menurut Ferdinand dalam (Hidayatullah, 2019) Kinerja Pemasaran merupakan takaran performa yang didapatkan dari kegiatan pemasaran secara komprehensif dari sebuah organisasi ataupun perusahaan. Selain itu, kinerja pemasaran juga dapat dilihat sebagai suatu konsep yang dimanfaatkan untuk menghitung sejauh mana prestasi pasar yang sudah diraih oleh suatu produk atau jasa yang dibuat oleh perusahaan. Kinerja pemasaran meruapakan faktor yang sering kali digunakan untuk mengukur dampak dan strategi yang diterapkan oleh perusahaan.}

\section{Jumlah Pembelian}

Pembelian adalah suatu usaha yang digunakan dalam perusahaan untuk pengadaan barang yang diperlukan oleh perusahaan. Secara umum definisi pembelian adalah usaha pengadaan barang atau jasa dengan tujuan yang akan digunakan sendiri, untuk kepentingan proses produksi maupun untuk dijual kembali, baik dengan atau tanpa proses, dalam proses pembelian yang ada, agar kegiatan pembelian dapat dilakukan dengan benar. (Indrajani, 2015)

Kalau bicara internet, maka kita akan bicara data. Untuk itu, untuk menujkan potensi yang sangat besar dari internet, maka saya akan menyajikan beberapa data. (CEO, n.d.)

\section{METODE PENELITIAN}

Penelitian kuantitatif umumnya berfokus pada pengukuran realitas sosial. Penelitian kuantitatif dibuat melalui permalasahan berupa pertanyaan atau pernyataan (kuesioner) untuk mencari kuantitas pada suatu gejala dan untuk membentuk penelitian secara numerik (Duli, 2019). Penelitian kuantitatif memandang dunia sebagai kenyataan yang dapat ditentukan secara objektif sehingga panduan yang tertata dalam proses pengumpulan dan analisis data sangat penting.

\section{Populasi}

Berasal dari bahasa Inggris yaitu Population yang berarti jumlah penduduk. Pengertian populasi dalam penelitian menurut para ahli sebagai berikut:

Populasi (Nurdin, Ismail dan Hartati, 2019) adalah keseluruhan subyek penelitian. Menurut Sabar dalam apabila seseorang hendak meneliti seluruh poin yang terdapat di area penelitian, maka penelitiannya adalah penelitian populasi atau studi populasi/studi sensen.

Menurut Sabar dalam (Nurdin, Ismail dan Hartati, 2019) Sampel adalah sepenggal dari subyek dalam populasi yang ditelaah eksperimen, dan tentunya sanggup secara cakap dan tepat yang dapat mewakili populasinya.

Populasi dalam penelitian ini adalah penduduk Kecamatan Cilincing Jakarta Utara. Berdasarkan data yang diperoleh dari Badan Pusat Statistik Kojata Jakarta Utara Dalam angka 2019 diperoleh jumlah populasi penduduk Cilincing sebanyak 425.358. Dari populasi tersebut kemudian diambil sampel dengan menggunakan rumus slovin sebagai berikut :

$$
\mathrm{n}=\frac{N}{1+N e^{2}}
$$

Ket:

$\mathrm{n}=$ jumlah sampel

$\mathrm{N}=$ jumlah populasi

$\mathrm{e}=$ batas toleransi kesalahan (error tolerance)

$$
\begin{aligned}
& n=\frac{425358}{1+425358 \times 0,05^{2}} \\
& n=\frac{425358}{1+425358 \times 0,0025} \\
& n=\frac{425358}{1064,395} \\
& n=399,624 \text { dibulatkan menjadi } 400
\end{aligned}
$$


Tabel 1. Variabel, Indikator dan Item Pertanyaan

\begin{tabular}{|c|c|c|}
\hline Variabel & Indikator & Item pertanyaan \\
\hline $\begin{array}{l}\text { Strategi } \\
\text { Pemasaran } \\
\text { (X1) } \\
\text { (Darmanto } \\
\text { dan } \\
\text { Wardaya, } \\
\text { 2016) }\end{array}$ & $\begin{array}{l}\text { Strategi } \\
\text { Orientasi } \\
\text { Pelanggan }\end{array}$ & 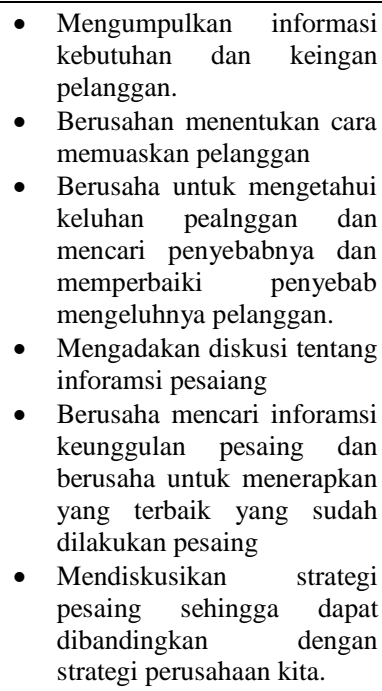 \\
\hline $\begin{array}{l}\text { Personal } \\
\text { Relevance } \\
\text { (PR) (X2) } \\
\text { (Campbell, } \\
\text { 2008) }\end{array}$ & $\begin{array}{l}\text { Relevansi } \\
\text { Ikan }\end{array}$ & $\begin{array}{ll}\text { - } & \text { Relevansi iklan dengan } \\
\text { histori pencarian (browsing) } \\
\text { - } & \text { Membantu memberikan } \\
\text { informasi kepada pelanggan } \\
\text { - } & \text { Membantu dalam } \\
\text { mencarikan informasi } \\
\text { kepada konsumen }\end{array}$ \\
\hline $\begin{array}{l}\text { Kinerja } \\
\text { Pemasaran } \\
\text { (Y) } \\
\text { Ferdinand } \\
\text { dalam } \\
\text { (Hidayatulla } \\
\text { h, 2019) }\end{array}$ & $\begin{array}{c}\text { Pertumbuhan } \\
\text { Pelanggan } \\
\text { (Y) }\end{array}$ & $\begin{array}{l}\text { - } \text { Omzet penjualan meningkat } \\
\text { setiap tahunnya } \\
\text { - Pertumbuhan penjualan tiket } \\
\text { masuk objek wisata } \\
\text { mengalami peningkatan } \\
\text { - Jumlah pengunjung yang } \\
\text { meningkat sertiap Minggu } \\
\text { - Pengunjung yang ada bukan } \\
\text { hanya dari kota malang } \\
\text { tetapi juga dari luar kota } \\
\text { Malang. } \\
\text { Pencapaian laba perusahaan } \\
\text { yang terus meningkat } \\
\text { Laba yang dihasilkan } \\
\text { perusahaan melebihi target } \\
\text { yang ada }\end{array}$ \\
\hline
\end{tabular}

\section{Hipotesis}

Semula istilah hipotesis berasal dari bahasa Yunani yang mempunyai dua kata "hupo" (sementara) dan "thesis" (pernyataan atau teori). (Siregar, 2017). Karena hipotesis merupakan pernyataan sementara yang masih lemah keasliannya, maka dibutuhkan uji kebenarannya. Kemudian para ahli menafsirkan arti hipotesis adalah asumsi terhadap hubungan antara dua variabel atau lebih. Penelitian lain yang dilakukan oleh (Asse, Ridho Azlam Ambo, 2018) yang berjudul Strategi Pemasaran Online (Studi Kasus Facebook Marketing Warunk Bakso Mas Cingkrank Di Makassar) menujukkan hasil penelitian bahwa facebook mengakomodasi komponen yang ada pada strategi komunikasi pemasaran seperti menyediakan data-data konsumen untuk memvalidasi segmentasi, targeting, dan positioning sekaligus menjadi bahan riset dalam menentukan produksi konten facebook marketing. Hal ini berarti menjelaskan bahwa strategi komunikasi pemasaran memainkan peran yang cukup penting dalam hal perdagangan. Penelitian serupa yang dilakukan oleh Karinda, ( Melanie V. A.,2018) etc yang berjudul Pengaruh Strategi Pemasaran Dan Inovasi Produk Terhadap Kinerja Pemasaran Produk Indihome PT.Telkom Area Tomohon menujukkan hasil penelitian bahwa menunjukkan bahwa strategi pemasaran berpengaruh signifikan terhadap kinerja pemasaran. Dalam hal ini maka dapat diambil kesimpulan bahwa semakin baik strategi pemasaran perusahaan kepada karyawan maka semakin baik pula kinerja pemasaran perusahaan. Dengan demikian dapat diartikan bahwa strategi pemasaran memiliki pengaruh terhadap kinerja pemasaran. Penelitian lain yang dilakukan oleh (Hendrawan, Andi etc,2019) dengan judul penelitian Pengaruh Marketing Digital Terhadap Kinerja Penjualan Produk UMKM Asti Gauri Di Kecamatan Bantarsari Cilacap menujukkan hasil bahwa ada pengaruh pemasaran digital terhadap kinerja penjualan produk UMKM di kabupaten Bantarsari. Hal ini memperlihatkan bahwa sistem pemasaran berbasis online memainkan peran yang cukup besar dalam kinerja penjualan, dengan kata lain metode pemasaran secara online akan memiliki pengaruh terhadap kinerja penjualan.

Atas dasar definisi di atas dapat diartikan bahwa hipotesis adalah jawaban atau dugaan sementara yang harus diuji kebenarannya.

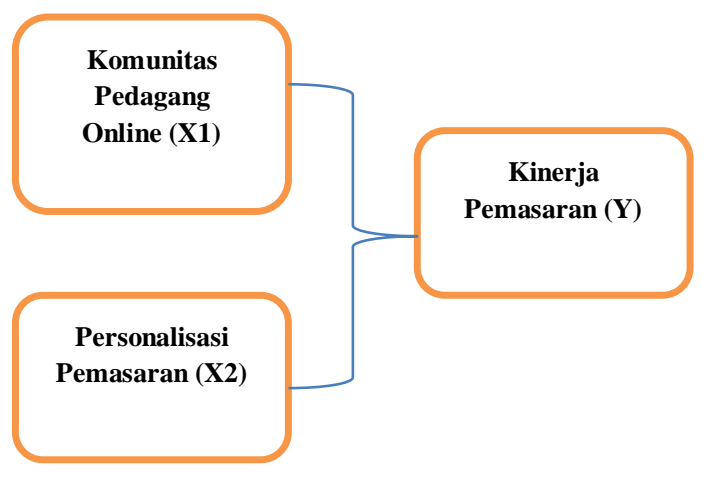

Gambar 2. Kerangka Berpikir 


\section{HASIL DAN PEMBAHASAN Validitas}

Validitas atau kesalihan adalah menujukkan sejauh mana suatu alat ukur mampu mengukur apa yang ingin diukur ( a valid measure if it succesfully measure the phenomenon ). (Siregar, 2017)

Mengingat pentingnya masalah validitas, maka tidak mengherankan apabila para pakar telah banyak berupaya untuk mengakaji masalah validitas serta membagi validitas ke dalam beberapa jenis, terdapat perbedaan pengelompokkan jenis-jenis validitas.

Nilai Corrected Item-Total Correlation lebih besar dari pada $\mathrm{R}$ tabel, maka dapat simpulkan bahwa item tersebut dinyatakan valid.

Hasil uji validitas menujukkan bahwa nilai Corrected Item-Total Correlation untuk masing-masing variabel Pemasaran Komunitas Berbasis Online (X1), Personalisasi Pemasaran (X2), Kinerja Pemasaran (Y) > R tabel.

Tabel 2. Uji Validitas Pemasaran Komunitas Berbasis Online (X1)

\begin{tabular}{|c|c|c|c|}
\hline No. & $\begin{array}{c}\text { r Pemasaran } \\
\text { Komunitas } \\
\text { Berbasis Online } \\
(\mathbf{X 1})\end{array}$ & r tabel & Keterangan \\
\hline 1. & 0,829 & 0,098 & Valid \\
\hline 2. & 0,872 & 0,098 & Valid \\
\hline 3. & 0,878 & 0,098 & Valid \\
\hline 4. & 0,582 & 0,098 & Valid \\
\hline 5. & 0,881 & 0,098 & Valid \\
\hline 6. & 0,919 & 0,098 & Valid \\
\hline 7. & 0,736 & 0,098 & Valid \\
\hline 8. & 0,840 & 0,098 & Valid \\
\hline 9. & 0,852 & 0,098 & Valid \\
\hline 10. & 0,927 & 0,098 & Valid \\
\hline 11. & 0,828 & 0,098 & Valid \\
\hline 12. & 0,681 & 0,098 & Valid \\
\hline 13. & 0,862 & 0,098 & Valid \\
\hline
\end{tabular}

Sumber: Data yang diolah dengan SPSS 20 (2020)

Tabel 3. Uji Validitas Pemasaran Personalisasi Pemasaran (X2)

\begin{tabular}{|c|l|l|l|}
\hline No. & $\begin{array}{l}\text { r Personalisasi } \\
\text { Pemasaran (X2) }\end{array}$ & r tabel & Keterangan \\
\hline 1. & 0,886 & 0,098 & Valid \\
\hline 2. & 0,835 & 0,098 & Valid \\
\hline 3. & 0,824 & 0,098 & Valid \\
\hline 4. & 0,618 & 0,098 & Valid \\
\hline 5. & 0,828 & 0,098 & Valid \\
\hline 6. & 0,860 & 0,098 & Valid \\
\hline 7. & 0,677 & 0,098 & Valid \\
\hline 8. & 0,845 & 0,098 & Valid \\
\hline 9. & 0,872 & 0,098 & Valid \\
\hline 10. & 0,873 & 0,098 & Valid \\
\hline 11. & 0,816 & 0,098 & Valid \\
\hline 12. & 0,755 & 0,098 & Valid \\
\hline 13. & 0,810 & 0,098 & Valid \\
\hline
\end{tabular}

Tabel 4. Uji Validitas Kinerja Pemasaran (Y)

\begin{tabular}{|c|l|l|l|}
\hline No. & \multicolumn{1}{|c|}{$\begin{array}{c}\text { r Kinerja Pemasaran } \\
(\mathbf{Y})\end{array}$} & r tabel & Keterangan \\
\hline 1. & 0,798 & 0,098 & Valid \\
\hline 2. & 0,893 & 0,098 & Valid \\
\hline 3. & 0,842 & 0,098 & Valid \\
\hline 4. & 0,505 & 0,098 & Valid \\
\hline 5. & 0,878 & 0,098 & Valid \\
\hline 6. & 0,845 & 0,098 & Valid \\
\hline 7. & 0,637 & 0,098 & Valid \\
\hline 8. & 0,784 & 0,098 & Valid \\
\hline 9. & 0,873 & 0,098 & Valid \\
\hline 10. & 0,851 & 0,098 & Valid \\
\hline 11. & 0,774 & 0,098 & Valid \\
\hline 12. & 0,873 & 0,098 & Valid \\
\hline 13. & 0,892 & 0,098 & Valid \\
\hline
\end{tabular}

Sumber: Data yang diolah dengan SPSS 20 (2020)

\section{Realibilitas}

Dalam konteks ilmu ststistik, terdapat beberapa teknik yang dapat digunakan untuk mengukur realibilitas suatu instrument penelitian, tergantung dari skala yang digunakan. Teknikteknik tersebut adalah teknik Cronbach's Alpha untuk skala bertingkat dengan kriteria keputusan jika koefisien realibilitas > 0.6 maka instrument penelitian dinyatakan reliabel. Siregar dalam (Duli, 2019)

\section{Pemasaran Komunitas Berbasis Online (X1)}

Tabel 5. Uji Realibilitas X1

Case Processing Summary

\begin{tabular}{|l|l|l|l|}
\hline \multicolumn{2}{|c|}{} & $\mathrm{N}$ & $\%$ \\
\hline \multirow{4}{*}{ Cases } & Valid $^{2}$ & 400 & 100.0 \\
\cline { 2 - 4 } & Excluded $^{\mathrm{a}}$ & 0 & .0 \\
\cline { 2 - 4 } & Total & 400 & 100.0 \\
\hline
\end{tabular}

a. Listwise deletion based on all variables in the procedure.

Sumber: Data yang diolah dengan SPSS 20 (2020)

Tabel 6. Uji Realibilitas X2

Personalisasi Pemasaran (X2) Case Processing Summary

\begin{tabular}{|l|l|l|l|}
\hline \multicolumn{2}{|c|}{} & $\mathrm{N}$ & $\%$ \\
\hline \multirow{4}{*}{ Cases } & Valid & 400 & 100.0 \\
\cline { 2 - 4 } & Excluded $^{\mathrm{a}}$ & 0 & .0 \\
\cline { 2 - 4 } & Total & 400 & 100.0 \\
\hline
\end{tabular}

a. Listwise deletion based on all variables in the procedure.

Reliability Statistics

\begin{tabular}{|l|l|}
\hline Cronbach's Alpha & N of Items \\
\hline .947 & 13 \\
\hline
\end{tabular}

Sumber: Data yang diolah dengan SPSS 20 (2020) 
Tabel 7. Uji Realibilitas Y

\section{Kinerja Pemasaran (Y)}

Case Processing Summary

\begin{tabular}{|l|l|l|l|}
\hline \multicolumn{2}{|c|}{} & N & $\%$ \\
\hline \multirow{3}{*}{ Cases } & Valid & 400 & 100.0 \\
\cline { 2 - 4 } & Excluded $^{\mathrm{a}}$ & 0 & .0 \\
\cline { 2 - 4 } & Total & 400 & 100.0 \\
\hline
\end{tabular}

a. Listwise deletion based on all variables in the procedure.

Reliability Statistics
\begin{tabular}{|l|l|}
\hline Cronbach's Alpha & N of Items \\
\hline .948 & 13 \\
\hline
\end{tabular}

Sumber: Data yang diolah dengan SPSS 20 (2020)

\section{Reliability Statistics}

\begin{tabular}{|l|l|}
\hline Cronbach's Alpha & N of Items \\
\hline .952 & 13 \\
\hline
\end{tabular}

Sumber: Data yang diolah dengan SPSS 20 (2020)

Berdasarkan hasil uji realibiltas diatas menujukan bahwa antara variabel X1 (0,952), X2 $(0,947)$ dan Y $(0,948)$ memiliki hasil Cronbach's Alpha $>0,6$.

\section{Pengertian Regresi Linier Berganda}

Regresi berganda adalah pengembangan dari regresi linier sederhana, yaitu sama-sama alat yang dapat digunakan untuk memprediksi permintaan di masa akan datang berdasarkan data masa lalu atau untuk mengetahui pengaruh satu atau lebih variabel bebas (independent) terhadap satu varibel tak bebas (dependent). Perbedaan penerapan metode ini hanya terletak pada jumlah variabel bebas (independent) yang digunakan. Penerapan metode regresi berganda jumlah variabel bebas (independent) yang digunakan lebih dari satu yang memengaruhi satu variabel tak bebas (dependent). (Siregar, 2017)

Tabel 8. Uji Regresi Berganda

Model Summary
\begin{tabular}{|l|l|l|l|l|l|}
\hline Model & $\mathrm{R}$ & $\begin{array}{l}\mathrm{R} \\
\text { Squar } \\
\mathrm{e}\end{array}$ & $\begin{array}{l}\text { Adjusted } \\
\text { R Square }\end{array}$ & $\begin{array}{l}\text { Std. Error } \\
\text { of the } \\
\text { Estimate }\end{array}$ & $\begin{array}{l}\text { Durbin- } \\
\text { Watson }\end{array}$ \\
\hline 1 & $.972^{\mathrm{a}}$ & .946 & .945 & 1.572 & 2.125 \\
\hline
\end{tabular}

a. Predictors: (Constant), Personalisasi Pemasaran (X2),

Pemasaran Komunitas Berbasis Online (X1)

b. Dependent Variable: Kinerja Pemasaran (Y)

Sumber: Data yang diolah dengan SPSS 20 (2020)

Hasil R Square atau $\mathrm{R}^{2}$ menujukkan angka 0,946 yang berarti bahwa sumbangan pengaruh Pemasaran Komunitas Berbasis Online (X1) dan Personalisasi Pemasaran (X2) terhadap Kinerja Pemasaran (Y) sebesar 94,6\% sedangkan sisanya $5,4 \%$ dipengaruh oleh variabel lain yang tidak diteliti dalam penelitian ini, seperti kemasan produk (packaging), harga produk (price) dan sebagainya.

\section{Uji Asumsi Klasik}

Uji asumsi klasik adalah persyaratan statistic yang harus dipenuhi pada analisis regresi linier berganda yang berbasis ordinary least square [OLS]. Uji asumsi klasik yang sering digunakan yaitu uji multikolinearitas, uji heteroskedastisitas, uji normalitas, uji autokorelasi dan uji linearitas. (Duli, 2019)

\section{Uji Normalitas}

Uji Normalitas bertujuan untuk melihat apakah nilai residual terdistribusi normal atau tidak. Model regresi yang baik adalah memiliki nilai residual yang terdistribusi normal. (Duli, 2019)

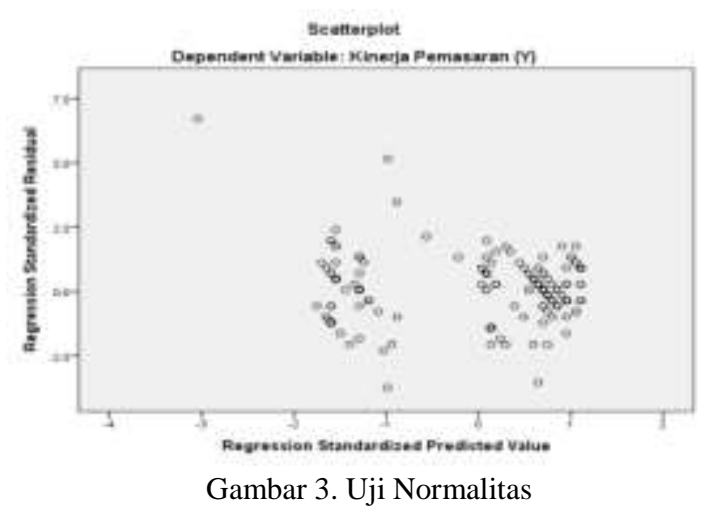

Sumber: Data yang diolah dengan SPSS 20 (2020)

Tabel 8. Uji Multikolinearitas

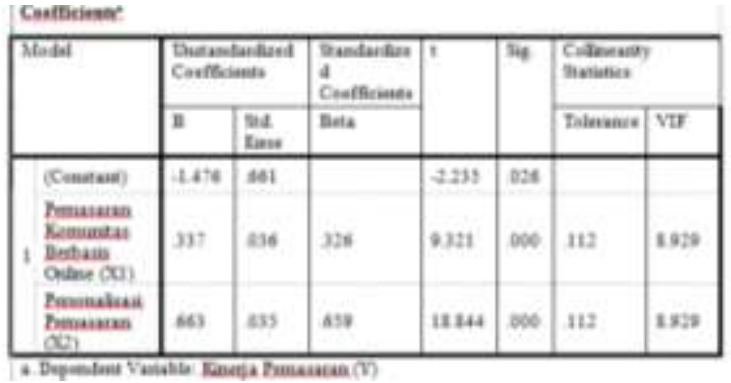

Sumber: Data yang diolah dengan SPSS 20 (2020)

\section{Uji Multikolinearitas}

Uji Multikolinearitas bertujuan untuk melihat ada atau tidaknya korelasi yang tinggi antara variabel-variabel bebas dalam suatu model regresi linear berganda. Menurut Widarjono dalam (Duli, 2019) jika ada korelasi yang tinggi di antara variabel-variabel bebasnya, maka hubungan antara variabel bebas terhadap variabel terikatnya menjadi terganggu. (Duli, 2019)

Alat statistik yang sering diperguanakan untuk menguji gangguan multikolinearitas adalah 
dengan variance inflation factor [VIF], korelasi pearson antara variabel-variabel bebas, atau dengan melihat eigenvalues dan condition index [CI].

Melihat nilai VIF (Variance Inflation Factor)

Jika nilai VIF $<10.00$ maka artinya tidak terjadi multikolinearitas terhadap data yang diuji.

Jika nilai VIF > 10.00 maka artinya terjadi multikolinearitas terhadap data yang diuji.

Berdasarkan hasil uji multikolinearitas diatas maka dapat disimpulkan bahwa nilai VIF sebesar $8.929<10.00$ maka dapat dismpulkan dari hasil uji diatas tidak terdapat gejala multikolinearitas.

\section{Uji F (Secara Simultan)}

Untuk menguji pengaruh varibel bebas secara bersama-sama atau simultan, diuji dengan menggunakan uji F. Hasil analisis regresi secara simultan dengan menggunakan SPSS diperoleh hasil pada tabel 9. (Amirudin, 2019)

Tabel 9. Uji F

\begin{tabular}{|c|c|c|c|c|c|}
\hline \multicolumn{6}{|c|}{ ANOVA $^{a}$} \\
\hline Model & $\begin{array}{l}\text { Sum of } \\
\text { Squares }\end{array}$ & $\mathrm{df}$ & $\begin{array}{c}\text { Mean } \\
\text { Square }\end{array}$ & $\mathrm{F}$ & Sig. \\
\hline Regression & 17048.424 & 2 & 8524.212 & $\begin{array}{r}3450 . \\
761 \\
\end{array}$ & $.000^{\mathrm{b}}$ \\
\hline Residual & 980.686 & 397 & 2.470 & & \\
\hline Total & 18029.110 & 399 & & & \\
\hline
\end{tabular}

Sumber: Data yang diolah dengan SPSS 20 (2020)

Tabel 9 menujukkan bahwa hasil analisis statistik yang diperoleh adalah nilai Fhitung = 3450.761 Ftabel $=3,01$. Dengan melihat perbandingan nilai $\mathrm{F}$ hitung dan $\mathrm{F}$ tabel, maka hasil yang diperoleh menujukkan bahwa nilai Fhitung = 3450.761 lebih besar dari Ftabel = 3,01.

Pengujian Hipotesis Secara Simultan (Uji Stattistik F) Uji F digunakan untuk menguji apakah variabel independen secara bersama-sama mempengaruhi variabel dependen. Dengan kata lain dapat disimpulkan bahwa pengambilan keputusan dalam uji $\mathrm{F}$ berdasarkan nilai $\mathrm{F}$ hitung dari $\mathrm{F}$ tabel.

Jika nilai $\mathrm{F}$ hitung $>\mathrm{F}$ tabel maka variabel independen secara simultan berpengaruh terhadap variabel dependen.

Jika nilai $\mathrm{F}$ hitung $<\mathrm{F}$ tabel maka variabel independen secara simultan tidak berpengaruh terhadap variabel dependen . . (Hartono, 2018)

Berdasarkan hasil perhitungan menujukkan bahwa nilai $\mathrm{F}$ hitung (3450.761)> F tabel $(3,01)$, maka disimpulkan bahwa variabel independen $\mathrm{X}$ (Pemasaran Komunitas berbasis Online dan Personalisasi Pemasaran) secara simultan berpengaruh terhadap variabel dependen Y (Kinerja Pemasaran) .

Selain itu hasil analisis dapat dilihat dengan menggunakan batas signifikansi. Jika tingkat signifikansinya dibawah 5\% maka secara simultan variabel independen berpengaruh terhadap varaibel dependen Ma'arif dalam ( Wati, Lina Asmara dan Primyastanto, Mimit, 2018). Berdasarkan hasil uji menujukkan tingkat signifikansi Pemasaran Komunitas berbasis Online (X1) dan Personalisasi Pemasaran (X2) dibawah dari 5\%, hal ini menujukkan bahwa secara simultan variabel Pemasaran Komunitas berbasis Online dan Personalisasi Pemasaran mempunyai pengaruh terhadap Kinerja Pemasaran

\section{KESIMPULAN}

Berdasarkan atas penelitian maka didapatkan kesimpulan sebagai berikut:

1. Hasil uji Regresi menujukkan bahwa sumbangan pengaruh Pemasaran Komunitas Berbasis Online (X1) dan Personalisasi Pemasaran (X2) terhadap Kinerja Pemasaran (Y) sebesar 94,6\% sedangkan sisanya 5,4\% dipengaruhi variabel lain yang tidak ditetili dalam penelitian ini.

2. Sementara itu untuk uji F secara simultan menujukkan bahwa Komunitas Pedagang Online dan Personalisasi Pemasaran mempunyai pengaruh terhadap Kinerja Pemasaran.

3. Semoga dengan dilakukannya penilitian ini dapat meningkatkan manfaat dan menambah pengetahuan belanja online bagi konsumen dan pedagang online.

\section{REFERENSI}

Amirudin. (2019). Pengaruh Etos Kerja, Disiplin dan Motivasi terhadap Kinerja Pegawai Pada Dinas Perindustrian dan Perdagangan Kabupaten Biak Numfor. Jawa Timur: Qiara Media.

Asse, Ridho Azlam Ambo.2018. Strategi Pemasaran Online (Studi Kasus Facebook Marketing Warunk Bakso Mas Cingkrank Di Makassar). Jurnal Komunikasi Kareba. Vol.7 No.2 Juli - Desember.

Campbell, D. E. dan R. T. W. (2008). "Shut-Up I Don't Care: Understanding The Role of Relevance And Interactivity On Customer Attitudes Toward Repetitive Online Advertising." Of Electronic Commerce Research, 9, 1.

CEO, M. (n.d.). Menghasilkan jutaan dari jualan online Kitab Jualan Online. Jawa Timur: Uwais Inspirasi Indonesia. 
Darmanto dan Wardaya, S. (2016). Manajemen Pemasaran Untuk Mahasiswa, Usaha Mikro, Kecil dan menengah. Yogyakarta: Deepublish.

databoks.katadata. (n.d.). Retrieved from https://databoks.katadata.co.id/datapublish/2 019/01/31/ini-e-commerce-indonesia-palingdiminati-pada-triwulan-iv-2018

Duli, N. (2019). Metodologi Penelitian Kuantitatif Beberapa Konsep Dsar Untuk Penulisan Skripsi \& Analisi Data dengan SPSS. Yogyakarta: Deepublish.

Hidayatullah, S. etc. (2019). Entrepreneurial Marketing. Jawa Timur: Uwais Inspirasi Indonesia.

Hartono.2018. Konsep Analisa Laporan Keuangan Dengan Pendekatan Rasio dan SPSS. Yogyakarta: Deepublish.

Hendrawan, Andi. 2019. Pengaruh Marketing Digital Terhadap Kinerja Penjualan Produk Umkm Asti Gauri Di Kecamatan Bantarsari Cilacap. Jurnal Administrasi dan Kesekretarisan. Volume 4 - Nomor 1 Maret.

Indrajani. (2015). DataBase Design. Jakarta: PT. Elex Media Komputindo.

Kristiadi. (2018). Manajemen Relasi Komunitas Online. Yogyakarta: ANDI.
Karinda, Melanie V. A. etc.2018. Pengaruh Strategi Pemasaran Dan Inovasi Produk Terhadap Kinerja Pemasaran Produk Indihome Pt.Telkom Area Tomohon. Jurnal EMBA Vol.6 No.3 Juli 2018, Hal. 1568 - 1577. ISSN 2303-1174.

Laoudon, Kenneth C. dan Laudon, J. P. (2008). Sistem Informasi Manajemen Edisi 10. Jakarta: Salemba Empat.

Nurdin, Ismail dan Hartati, S. (2019). Metodologi Penelitian Sosial. Surabaya: Media Sahabat Cendekia.

Ramadhan, A. A. (2013). Female NetPreneurs. Jakarta.

Rusmanto. (2017). Modul Pratikum Manajemen Pemasaran Berbasis IT. Sekolah Tinggi Teknologi Terpadu Nurul Fikri.

Siregar, S. (2017). Metode Penelitian Kuantitatif. Jakarta: Kencana Prenada Media Group.

Wati, Lina Asmara dan Primyastanto, Mimit, 2018. Ekonomi Produksi Periklanan dan Kelautan Modern Teori dan Aplikasinya. Malang: UB Press 